\title{
Public Rationality in China: an important cornerstone of social governance
}

\author{
Yang qianqian \\ Yunnan University of finance and economics law school \\ Boyuan Bldg., 237 Longquan Rd. \\ Kunming, Yunnan, China \\ (Helenyang69@gmail.com)
}

\begin{abstract}
Under the background of the conflict with multiculture and the values, and the current politics, life, values are closely related, which help to relieve social contradictions. Public reason is a kind of rational cognition that is also a kind of public morality and the public body free and fair rational, the realization of social equality and justice and promote the harmonious development between the social public affairs, also the moral cognition and the unity. In the process of social development, public rationality is the important foundation of a harmonious society, which provides a measure of the maturity of the rule of law, and provides the value orientation for civic education.
\end{abstract}

Keywords—public rationality; social governance; democracy

\section{INTRODUCTION}

In the era of the coexistence of multiple cultures, public rationality has become an important concept in western political philosophy. However, the definition of the concept of public rationality has experienced Hobbes, Rousseau, Kant, Rawls, Habermas and other philosophers to explain it.

The concept of public rationality can be traced back to Hobbes's "supreme agent's rationality". According to Hobbes's opinion, people should obey the public reason and give up the rational judgment of the facts. Public rationality is the "supreme agent", but Hobbes did not explain why the "supreme agent" compared with individual rationality of superiority. Rousseau in "social contract theory" pointed out that "the law only considers the community of subjects and abstract behavior, but never consider a person and individual behavior." He thinks the public reason is that people abide by the common participation in the establishment of the law, also named "public opinion". Rousseau believed that people were born and free, in order to solve the contradiction between freedom and social conflict, the best way was to make laws and follow the law. The public rationality of Rousseau phase compared with Hobbes's public reason was more respect the freedom of individuals; the public reason is transferred from the hands of the "highest agent" in building their own. To some extent, Kant's concept of public reason inherits Rousseau's viewpoint. With the combination of Kant's reason and enlightenment, he thinks some subjective reasons lead that human is not able to use their rational, then after the enlightenment, the use of human's own reason, "from themselves in addition to their immaturity". However, the Enlightenment of public reason, he thought "the public to enlighten itself, as long as they allow freedom", Kant regarded public reason as to a rational based on human freedom, also had the universality of human reason. Rawls's public rationality benefits from the influence of Kant's concept of reason. The difference is that he puts the public rationality in the political philosophy and no longer in the moral philosophy. He believes that public rationality is the rational principle used to dealing with public life, and it is not used to limiting the freedom of individual life rather to respect individual freedom as the premise. Rawls distinguished the concept between public reason and non-public reason. At the same time, he distinguished "rational" from "reasonable". The premise of freedom of public rationality shows its universality and public nature. Public rationality is a guide to public inquiry, and it also makes this kind of research into free and public. In addition to the political and philosophical significance of Rawls's definition of public reason, it also promotes the development of human rights, fairness and justice. He appealed to a rational, which was based on human freedom and respected for human equality to achieve a deeper level of public rationality. Habermas put forward to the concept of public sphere on the basis of public rationality. His works of the public sphere structure transformation criticized social problems on rational analysis. He will regard public realm of capitalism as a measure for analyzing the problems in the development of contemporary society and providing direction for the transformation and construction of contemporary society.

\section{The Connotation of Public Rationality}

Public rationality is a kind of cognitive rationality. The public reason combines the individual rationality with social reason, and from the individual's reason, in order to seek common and harmonious public reason, and to create a fair, equal and free public platform. The rationality of the public is not all the individual rational integration among the entire society, such integration is still dispersed for society and it can't play positive role, which is difficult to make the social to norms of equality and justice. The premise of the public reason is that every citizen can accept it, the purpose is to realize the equality and freedom of the citizens. It can be seen that the cognitive rationality of the public reason is fundamentally the cognition of democracy.

In terms of thinking, the public reason is a win-win way of thinking. And the way of thinking is influenced by the social and cultural background. For example, the Chinese traditional 
culture aims at considering the global thinking, emphasizing the "harmony between man and nature", but there are many defects on the details of the deal. The role of public reason is to overcome the loopholes in all kinds of thinking and examine public affairs in the view of public reason. The cognition of public rationality is public, objective, overall, and win-win. The cognition of public reason first requires that the maximum of individual reason and beyond the individual reason can reach the balance of the society as far as possible, from the aspect of public interest. Secondly, the cognition of public reason is also objective, and should not be personal. Scientific analysis and treatment must be based on the objective facts. The cognition of the public rationality is also the totality, and carries on the conformity to all individual rationality. Finally, the public rationality is a win-win situation, which is in order to adapt to and deal with the differences and conflicts caused by multicultural background, so as to achieve the harmonious development of public subjects and to avoid the possible contradictions between the public. The cognition of public reason must respect the Democratic will of the citizen, but not be limited to the limitation of the right organ at present.

Public reason is a kind of public morals, advocating people from the point of view of the public interest of using rational norms of social behavior and the expression of ideas of justice. Contemporary public rationality and Hobbes were not different from the public reason proposed by the time that did not control in the sovereign, nor is it a strong means to force citizens to comply with the requirements of its. In order to realize the citizen's freedom, democracy, the public reason, must have certain public morals. In essence, the public morality is the public good that is, the citizen's obligation on the basis of fairness. In order to realize the effective development of public rationality and respect the premise of public rationality of civil liberty, fairness and justice, it is inevitable that the citizen should have the obligation to the public reason.

The establishment of public reason can effectively make the social order in a fair and equitable way. On the contrary, good social order can urge citizens to feel obliged to maintain and develop the public order, and have better support and reason for the public reason. Public moral needs to be established based on democracy for meeting the needs of civil society, and the establishment of the public moral need is established from a win-win situation, the overall level, public morals and public reason are closely related to. As the Eighteenth National Congress of the CPC the core values of the socialist view of prosperity, democracy, civilization, harmony and freedom, equality, justice and the rule of law, patriotism, dedication, integrity, kindness, these moral values are from the different level guide citizen life and the social order giving social development moral guidance provides, which is conducive to the sustainable development of society.

The public reason is the wisdom of the public affairs, which represents the public, public opinion, democratic. At the same time, the public reason is constantly developing, not only it can be effectively used in the current social expectations, but also need to adapt to the social development, and contribute to the progress of the society. Whether it is a country, a society or a citizen, it needs to have a sense of public awareness. Current China's social development facing the unexpected mass incidents, a large part of the reason is that citizen is lack of public reason to judge things and the relevant departments to deal with unexpected events that does not have enough public reason to resolve social contradictions. Therefore, the public reason is very important for the development of social stability. From Kant's point of view, reason needs enlightenment, and the Enlightenment of public reason should be based on democracy, which is of great significance on the healthy development of our country.

On the one hand, public rationality is the rational thinking of the citizens to own; on the other hand, it is a rational analysis of the social stratification. Civil reason makes the citizen from the traditional passive dependent to become independent and active role. Rational citizen development is helpful to promote social fairness, freedom, alleviate social contradictions and enable citizens to be in a proactive way objective consideration of public affairs, and win-win perspective to regulate their own code of conduct and to promote social harmonious development.

\section{The Important VAlue of Public RATIONALITY TO SOCIAL GOVERNANCE}

1.The public reason is the important foundation of building a democratic and harmonious society. In the context of diversified society, it is bound to produce various contradictions, the alienation of public affairs and individuals, and the failure of moral norms and so on. As a rational way of thinking, public rationality cultivates the concept of citizen independence and mutual benefit, which is helpful to the government's management of the society. "Public reason is various political subjects (including citizens, all kinds of community and governmental organizations) to the concept of justice, free and equal status, in the social and political of public affairs, such a long-standing cooperation system, were full of cooperation, the ability to generate public, can be expected that the governance effect." The construction of public rationality and social governance complement each other, which is a necessary condition for the rule of law to mature, and the development of public rationality can promote the practice of the rule of law society better.

2. The public rationality is a measure of the rule of law society that is mature or not. "The legalization of the state power and civil society are inseparable from the public reason; at the same time, public right and private right force, which is the trend of equalization of public rights and private rights marks maturity of society under the rule of law." Therefore, the public reason is the inevitable demand of the mature rule of law society. At the same time, the development of public reason is to follow the development of the times and adapt to the development of the times.

3. Public rationality is the value orientation of civic education. Civic education focuses on the basic values of social life to the citizens, and for adapting to the social and cultural, economic and political values. Fairness, justice and the equal rights of discourse development in respect of 
contemporary society, the public reason in terms of cognitive, moral qualities of the citizens to enhance, cultivating moral quality of citizen cooperation, communication, tolerance, for equality, mutual benefit and win-win to solve social and life problems.

\section{CONCLUSION}

Chinese society is in the stage of development, facing with various challenges brought by diverse cultural background, social contradictions emerge in an endless stream. On the one hand, China has long been influenced by the traditional culture, and the traditional culture has been difficult to meet the modern social mechanism and social ethics. At the same time, the traditional culture and the impact of modern culture, with the country's opening up, the Western cultural values and ethics of a large number of input, towards the domestic community, public affairs, as well as the great impact of the citizens. Western individualism and the traditional collectivism collide with each other, then the current society pay more attention to democracy, fairness and justice. Therefore, what are given to our country not only in culture, life, at the same time for politics, state governance, and other levels to bring a lot of challenges. On the other hand, the country did not establish a complete value system, which is the same as influenced by Western values, value view of mutual fusion and conflict, and even some extreme to consumerism, materialism, pragmatism guided by economic interest. And the establishment of the democratic system is not yet mature, although the country began to pay attention to democracy, but the lack of citizens in the sense of public awareness, often lead to many extreme public affairs. Moreover, there are still many social problems in the western society, and the values of their values are introduced into China, which leads to some confusion. Therefore, the public reason is very important to the social governance. Public reason is on behalf of the citizens in the fairness and justice of the public level common rationality, neither in a small fraction of an individual reason instead of the rationality of the whole society, nor abandon individual rationality, but to achieve the harmony of the individual and society and provides equal dialogue platform for citizens to live in freedom and democracy. The mature development of society needs the sound system and the rational development of the social citizen. In order to realize the ideal goal of harmonious coexistence of multiple values in Chinese society, the enlightenment and development of public rationality is of great significance to social governance.

\section{ACKNOWLEDGMENT}

I would like to thank Professor PengNai for his comments on this paper and Research project of the work mechanism of community correction in the Judicial Bureau of tranquility for their research assistance.

\section{REFERENCES}

[1] Habermas, Jürgen, (Trans. William Rehg) Between Facts and Norms: Contributions to a Discourse Theory of Law and Democracy, Cambridge, Mass.: The MIT Press, 1996, pp.45-62.

[2] Hobbes, T., 1640, the Elements of Law, in J.C.A. Gaskin (ed.) the Elements of Law, Natural and Politic, Oxford: Oxford University Press, 1990, pp.210-213.

[3] Hobbes, T., 1651, Leviathan, in E. Curley (ed.) Leviathan, Indianapolis: Hackett, 1994, pp.125-136.

[4] Plato, (Trans. G.M.A. Grube) Five Dialogues, Hackett Publishing Company, 1981, pp.59-67.

[5] Plato, (Trans. G.M.A. Grube) Republic, Hackett Publishing Company, 1992, pp.123-145.

[6] Rawls, John. A Theory of Justice, Harvard University Press,1971, pp.69152.

[7] Rawls, John. Political Liberalism, Columbia University Press,1993, pp.59123.

[8] Rousseau, Jean-Jacques, the Basic Political Writings. (Trans. Donald A. Cress) Hackett Publishing Company,1987, pp.8-42.

[9] Sandel, Michael, Liberalism and the Limits of Justice, Cambridge: Cambridge University Press,1982, pp.105-117.

[10]Vallentyne, Peter. (Editor) Contract arianism and Rational Choice: Essays on David Gauthier's Morals by Agreement. New York: Cambridge University Press, 1991, pp.51-60. 